\title{
Effects of Different Source of Dietary Non-Starch Polysaccharides on Growth Performance, Physiological Characteristics and Gene Expression of GLUT2 in Chickens
}

\author{
Majid Kalantar ${ }^{1,2, a *}$ and Mohammad Hassan Kalantar ${ }^{3, b}$ \\ ${ }^{1}$ Department of Animal Science, Qom's Agriculture and Education Research Center, \\ Agricultural Research, Education and Extension Organization, IR Iran, P.O Box: 195 \\ ${ }^{2}$ Department of Animal Science, Agricultural Faculty, Shahrekord University, Shahrekord, \\ IR Iran P.O Box: 165 \\ ${ }^{3}$ Student Research Committee, Arak University of Medical Science, Arak, Iran. \\ am2332012@gmail.com, bmh.kalantar@Arakmu.ac.ir
}

Keywords: Chicken, Gene expression, GLUT2, NSP, Physiological characteristic.

\begin{abstract}
Growth and physiological characteristics of meat-type chicken such as serum immunoglobulin concentration, digesta $\mathrm{pH}$ and viscosity, pancreatic enzyme activity, organelle weights, and gene expression of intestinal GLUT2 of chickens was studied by means of 375 day-old chicks which randomly assigned to three treatments with five replicates in a completely randomized design. Two different types of cereal-based diets (wheat, and barley) were used as experimental groups and a corn-based diet was also considered to serve as control group. All diets had similar contents of crude protein, energy, and total non-starch polysaccharides (NSP). Results indicated that different dietary source of NSP had significantly $(\mathrm{P}<0.01)$ affected growth traits, so barley and wheat diets had maximum feed intake and feed conversion rate, inversely minimum weight gain than corn diet. Intestinal physicochemical characteristics such as $\mathrm{pH}$ and viscosity of digesta significantly $(\mathrm{P}<0.01)$ changed by different dietary source of NSP. Wheat and barley diets had minimum $\mathrm{pH}$, and inversely maximum viscosity compared to corn diet. The maximum values of fat pad and liver percentage, in contrary, minimum values of pancreas and gut length belonged to corn diet $(\mathrm{P}<0.01)$. Serum immunoglobulin concentrations of $\operatorname{IgG}$ and $\operatorname{IgM}$ for wheat and barley diets were higher than their counterparts fed on corn $(\mathrm{P}<0.01)$. Gene expression of intestinal GLUT2 of chickens based on mean fold change after feeding of wheat or barley was at upper level compared to corn diet $(\mathrm{P}<0.01)$. In conclusion, based on findings of present study, feeding of different dietary NSP sources to broiler chickens significantly affected growth traits and internal organelle percentages, as well as physiological and immune responses. Also gene expression of intestinal GLUT2 well affected by cereal NSP sources through feeding of wheat or barley.
\end{abstract}

\section{Introduction}

The main ingredient of poultry feedstuff is corn grain, but alternatively other cereal grains can be successfully used instead of corn in poultry diets. Wheat and barley are generally used as embedment of corn to supply energy in poultry diets. Though the primary components of these grains are starch and proteins, but considerable content of non-starch polysaccharides (NSPs) derived from the cell walls of these cereals $[26,30]$. Since toxic materials, the primitive antinutritional factor in the cereal grains is generally considered as NSPs [17]. Different grains have disparate content of NSP polymers which significantly vary between cereals and consequently affect their alimentary value and anti-nutritional impacts [30]. The backbone of NSPs in wheat is constituted by arabinoxylan polymers, whereas the backbone of NSPs in barley comprises polymers of $\beta$-glucans $[6,17,42]$. A literature review of corresponsive reports indicates that NSPs from different sources of cereal grains have various adverse effects on health and physiological characteristics of poultry $[6,19,21]$. Attendance of anti-nutritive compounds in the gut causing increase in product shelf life, along with undesirable physicochemical properties in digesta [7-9], and negative impact on the quantity and quality of relevant gene expression $[3,31,36]$. Level of 
NSPs consumed well over several days increases the concentration of glucose transporters as well as amino acid transporters in the intestinal cell membrane and this means increasing levels of mRNA in the enterocytes $[10,11]$. There is limited information on the impact of different NSP sources on expression of intestinal nutrient transporters under such circumstances. In the present study, different sources of NSP from corn, wheat and barley were included in chicken diets to study the effects on growth, serum immunoglobulin concentrations, digesta $\mathrm{pH}$-viscosity, pancreatic enzyme activity of $\alpha$-amylase and lipase, and gene expression of intestinal glucose transporter2 (GLUT2).

\section{Materials and Methods}

\section{Chickens, management and treatments}

A total number of 375 day-old broiler chickens (Ross-308 strain) were randomly assigned to three treatments and five replicates of 25 chicks each. Each replicate was a floor pen of $1.5 \times 2.2 \mathrm{~m}^{2}$. Three experimental diets based on $\operatorname{corn}(\mathrm{C})$, wheat $(\mathrm{W})$, and barley was formulated for birds according to NRC recommendations [29]. Corn, wheat and barley samples were analyzed based on A.O.A.C instructions [1] before the experiment for non-starch polysaccharide constituents, which depicted in Table 1. All cereal-based diets were formulated to have equal fractions of soluble NSP.

Table 1. Non-starch polysaccharide constituents of cereal samples before the experiment [\%]

\begin{tabular}{|c|c|c|c|c|c|c|c|}
\hline Sample & Cellulose $^{1}$ & $\begin{array}{c}\text { Hemi- } \\
\text { Cellulose }^{2}\end{array}$ & $\begin{array}{c}\text { Lignin }^{3} \\
(\text { ADL })\end{array}$ & $\begin{array}{c}\text { Total } \\
\text { NSP }\end{array}$ & $\begin{array}{c}\text { Soluble } \\
\text { NSP }\end{array}$ & $\begin{array}{c}\text { Insoluble } \\
\text { NSP }\end{array}$ & DF $^{4}$ \\
\hline $\begin{array}{c}\text { Corn } \\
( \pm \text { SE })\end{array}$ & $\begin{array}{c}1.2 \\
( \pm 0.12)\end{array}$ & $\begin{array}{c}6.4 \\
( \pm 0.32)\end{array}$ & $\begin{array}{c}0.86 \\
( \pm 0.08)\end{array}$ & $\begin{array}{c}11.23 \\
( \pm 0.45)\end{array}$ & $\begin{array}{c}1.83 \\
( \pm 0.11)\end{array}$ & $\begin{array}{c}9.40 \\
( \pm 0.39)\end{array}$ & $\begin{array}{c}9.84 \\
( \pm 0.58)\end{array}$ \\
\hline Wheat & 1.8 & 10.4 & $\begin{array}{c}1.59 \\
( \pm \text { SE })\end{array}$ & $\begin{array}{c}13.11 \\
( \pm 0.10)\end{array}$ & $\begin{array}{c}2.45 \\
( \pm 0.52)\end{array}$ & $\begin{array}{c}10.66 \\
( \pm 0.18)\end{array}$ & $\begin{array}{c}14.7 \\
( \pm 0.64)\end{array}$ \\
\hline $\begin{array}{c}\text { Barley } \\
( \pm \text { SE })\end{array}$ & $\begin{array}{c}4.4 \\
( \pm 0.24)\end{array}$ & $\begin{array}{c}23.62 \\
( \pm 1.42)\end{array}$ & $\begin{array}{c}1.97 \\
( \pm 0.24)\end{array}$ & $\begin{array}{c}16.73 \\
( \pm 0.81)\end{array}$ & $\begin{array}{c}4.12 \\
( \pm 0.15)\end{array}$ & $\begin{array}{c}12.61 \\
( \pm 0.65)\end{array}$ & $\begin{array}{c}18.7 \\
( \pm 0.94)\end{array}$ \\
\hline
\end{tabular}

1: Cellulose=ADF-ADL; 2: Hemi-Cellulose=NDF-ADF; 3: Lignin (ADL) = ADF-Cellulose; 4: Dietary Fiber=Total NSP +ADL.

Feed and water were provided at free access. Environmental conditions including temperature and lighting schedule followed the management guideline of the Ross-308 strain. The experimental animals were kept, maintained and treated in accordance with the standards in the guide for the care and use committee of Qom's agriculture and education research center.

\section{Measurements}

Feed intake, weight gain, and feed conversion ratio (FCR) was calculated as total mean values. On 42 days of ages, 3 birds from each replicate were randomly selected and slaughtered to measuring the weight and percentage of internal organelles, also blood samples were taken from wing vein before slaughtering, and were transferred to vial tubes containing sodium heparin. The tubes were centrifuged at $5000 \times \mathrm{g}$ for $20 \mathrm{~min}$, and the supernatant was discarded. Serum immunoglobulin concentrations including $\mathrm{IgG}$ and $\mathrm{IgM}$ were measured using 2-mercaptoethanol indicator method according to the procedure of Akbari Gharaei et al. [2] with some minor changes. Digesta samples were obtained from selected slaughtered birds to measure digesta $\mathrm{pH}$ and viscosity parameters according to the procedure of Langhout et al. [22] with some minor changes.

\section{Gene Expression of GLUT2}

Pieces of jejunum tissue of slaughtered chickens were used to measuring expression of GLUT2 genes. Extraction of RNA from jejunum samples were done via the standard RNA 
purification kit (CINNAPURE RNA Purification Kit, Sina gene Co, Tehran, Iran) according to manufacturer directions. Synthesis of cDNA from mRNA samples was done using transcription kit (Reverse Transcription kit, Qiagen Co) according to manufacturer directions. RT-PCR processes were performed by ABI device model 7500, USA using specific primers of $\beta$-actin as reference gene and specific primers of poultry as experimental groups (Metabion, Co, Germany) and QuantiFast produced by Qiagen Co, TM SYBR. Sequencing and characteristics of primers depicted in the table 2. For measuring the gene expression of the experimental groups $\mathrm{Ct}$ index were calculated and then comparing the $\mathrm{Ct}$ index for the target and reference genes were performed. Gene expression levels were determined via calculating the parameter of $2-\Delta \Delta \mathrm{Ct}$ according to equation (1), based on method of Livak and Shcmittgen [23].

$\Delta \Delta \mathrm{Ct}=(\mathrm{Ct}$ mean target gene $-\mathrm{Ct}$ mean $\beta$-actin $)-(\mathrm{Ct}$ mean control gene $-\mathrm{Ct}$ mean $\beta$-actin $)$

Table 2. Genes and Primers specifications

\begin{tabular}{|c|c|c|c|c|c|}
\hline $\begin{array}{c}\text { Gene } \\
\text { name }\end{array}$ & $\begin{array}{c}\text { Gene } \\
\text { code }\end{array}$ & Gene action & Forward primer & $\begin{array}{c}\text { Backward } \\
\text { primer }\end{array}$ & $\begin{array}{c}\text { Chain } \\
\text { Length } \\
\text { (base pair) }\end{array}$ \\
\hline GLUT2 & Z22932 & $\begin{array}{c}\text { Na+-independent } \\
\text { glucose and } \\
\text { galactose and } \\
\text { fructose transporter }\end{array}$ & $\begin{array}{c}\text { CCGCAGAAGGTG } \\
\text { ATAGAAGC }\end{array}$ & $\begin{array}{c}\text { ACACAGTGGG } \\
\text { GTCCTCAAAG }\end{array}$ & 181 \\
\hline$\beta$-actin & L-8165 & Reference Gene & $\begin{array}{c}\text { GTCCACCGCAAA } \\
\text { TGCTTCTAA }\end{array}$ & $\begin{array}{c}\text { TGCGCATTTAT } \\
\text { GGGTTTTGTT }\end{array}$ & 270 \\
\hline
\end{tabular}

\section{Statistical procedures}

The results were statistically analyzed by GLM procedure of SAS software of SAS Institute Inc [35]. Statistical scheme was based on completely randomized design (CRD). Samples within pens ( 3 per each unit) were subjected to nested analysis. Duncan's multiple range tests was used to separate the means.

\section{Results}

\section{Growth performance}

Table 3 depicts the total mean values of feed intake, weight gain, and feed conversion ratio of chickens at the end of trial. Results indicated that birds fed wheat significantly $(\mathrm{P}<0.01)$ reduced their feed intake compared to other groups. Birds fed barley had significantly increased feed intake compared to the wheat and corn diets $(\mathrm{P}<0.01)$. Nevertheless, birds fed on barley and wheat diets had significantly lower body weight and higher feed conversion ratio (FCR) than their counterparts fed on corn diet $(\mathrm{P}<0.01)$.

Table 3. Effect of different NSP sources on growth traits of chickens

\begin{tabular}{|c|c|c|c|}
\hline Treatments & $\begin{array}{c}\text { Total feed } \\
\text { intake [kg/bird] }\end{array}$ & $\begin{array}{c}\text { Total weight gain } \\
{[\mathbf{k g} / \mathbf{b i r d}]}\end{array}$ & $\begin{array}{c}\text { Feed conversion } \\
\text { ratio [FCR] }\end{array}$ \\
\hline C & $4280.30^{\mathrm{b}}$ & $2251.30^{\mathrm{a}}$ & $1.90^{\mathrm{b}}$ \\
\hline W & $4164.20^{\mathrm{c}}$ & $2015.70^{\mathrm{b}}$ & $2.07^{\mathrm{a}}$ \\
\hline B & $4333.30^{\mathrm{a}}$ & $2107.30^{\mathrm{b}}$ & $2.06^{\mathrm{a}}$ \\
\hline SEM & 25.56 & 22.13 & 0.05 \\
\hline
\end{tabular}

\footnotetext{
${ }^{*}$ abc Means with different superscript letters within columns have significant difference $(\mathrm{P}<0.01)$. ${ }^{*} \mathrm{C}$ :corn,
} W:wheat, B:barley. SEM: Standard Error of Mean. 


\section{Intestinal $\mathrm{pH}$ and viscosity}

According to the results of table 4, digesta $\mathrm{pH}$ of birds fed on corn diet was significantly $(\mathrm{P}<0.01)$ higher than wheat or barley diets, but adversely, digesta viscosity of birds fed on wheat and barley were higher than their counterparts fed on corn diet $(\mathrm{P}<0.01)$.

Table 4. Effect of different NSP sources on intestinal $\mathrm{pH}$ and viscosity of chickens

\begin{tabular}{|c|c|c|}
\hline Treatments & Digesta pH & Diesta Viscosity (Cp) $^{\mathbf{1}}$ \\
\hline $\mathrm{C}$ & $6.89^{\mathrm{a}}$ & $1.59^{\mathrm{c}}$ \\
\hline $\mathrm{W}$ & $5.93^{\mathrm{b}}$ & $2.17^{\mathrm{a}}$ \\
\hline $\mathrm{B}$ & $5.67^{\mathrm{b}}$ & $1.95^{\mathrm{b}}$ \\
\hline SEM & 0.11 & 0.05 \\
\hline
\end{tabular}

*abc Means with different superscript letters within columns have significant difference $(\mathrm{P}<0.01) .{ }^{1} \mathrm{Cp}$ : Centipoise. *C:corn, W:wheat, B:barley. SEM: Standard Error of Mean.

\section{Internal organelle weight}

Table 5 shows the mean percentage of internal organelle weights and mean gut length of chickens after feeding of different dietary sources of NSP. These results indicated that birds fed on corn diet significantly $(\mathrm{P}<0.01)$ increased their abdominal fat (fat pad) compared to wheat or barley groups. Whilst birds fed on barley had significantly $(\mathrm{P}<0.01)$ reduced fad pad compared to wheat or corn groups, and birds fed on wheat was on midpoint. Accordingly, the liver percentage of birds fed on corn was significantly $(\mathrm{P}<0.01)$ higher than wheat and barley diets, but pancreas percentage and gut length of birds fed on wheat or barley were significantly $(\mathrm{P}<0.01)$ higher than their counterparts fed on corn diet $(\mathrm{P}<0.01)$.

Table 5. Effect of different NSP sources on internal organelle weight of chickens [\% of body weight]

\begin{tabular}{|l|c|c|c|c|}
\hline Treatments & $\begin{array}{c}\text { Fat pad } \\
\text { \% }\end{array}$ & $\begin{array}{c}\text { Liver } \\
\%\end{array}$ & $\begin{array}{c}\text { Pancreas } \\
\text { \% }\end{array}$ & $\begin{array}{c}\text { Gut length } \\
\text { (cm) }\end{array}$ \\
\hline C & $1.26^{\mathrm{a}}$ & $2.07^{\mathrm{a}}$ & $0.07^{\mathrm{b}}$ & $85.16^{\mathrm{b}}$ \\
\hline W & $1.09^{\mathrm{b}}$ & $1.95^{\mathrm{b}}$ & $0.09^{\mathrm{ab}}$ & $92.81^{\mathrm{a}}$ \\
\hline B & $0.9^{\mathrm{c}}$ & $1.87^{\mathrm{b}}$ & $0.11^{\mathrm{a}}$ & $97.05^{\mathrm{a}}$ \\
\hline SEM & 0.11 & 0.08 & 0.02 & 3.30 \\
\hline
\end{tabular}

*abc Means with different superscript letters within columns have significant difference $(\mathrm{P}<0.01) .{ }^{*} \mathrm{C}$ :corn, W:wheat, B:barley. SEM: Standard Error of Mean.

\section{Serum immunoglobulin concentrations}

Table 6 demonstrates changes of mean serum immunoglobulin concentrations of chickens after feeding of different dietary sources of NSP at age of 42 days. Serum IgG and IgM titer of birds fed on wheat diet was significantly $(\mathrm{P}<0.01)$ higher than their counterpart fed on corn $\operatorname{diet}(\mathrm{P}<0.01)$.

Table 6. Effect of different NSP sources on serum immunoglobulin concentrations of chickens [Based on $\log _{2}$ ]

\begin{tabular}{|c|c|c|c|}
\hline Treatments & IgG titer & IgG & IgM titer \\
\hline $\mathrm{C}$ & $2.42^{\mathrm{a}}$ & $2.42^{\mathrm{b}}$ & $2.67^{\mathrm{b}}$ \\
\hline $\mathrm{W}$ & $2.00^{\mathrm{b}}$ & $2.85^{\mathrm{a}}$ & $3.33^{\mathrm{a}}$ \\
\hline $\mathrm{B}$ & $1.63^{\mathrm{c}}$ & $2.63^{\mathrm{ab}}$ & $2.98^{\mathrm{ab}}$ \\
\hline SEM & 0.11 & 0.11 & 0.13 \\
\hline
\end{tabular}

*abc Means with different superscript letters within columns have significant difference $(\mathrm{P}<0.01)$. *C:corn, W:wheat, B:barley. SEM: Standard Error of Mean. 


\section{Gene Expression of GLUT2}

Table 7 demonstrates changes of gene expression of intestinal GLUT2 of chickens after feeding of different dietary sources of NSP. Expression of intestinal GLUT2 gene of birds fed on wheat or barley diets were significantly $(\mathrm{P}<0.01)$ higher than their counterparts fed on corn diet $(\mathrm{P}<0.01)$. Expression of $\beta$-actin gene for whole of treatments was not significantly different.

Table 7. Effect of different NSP sources on expression of intestinal GLUT2

\begin{tabular}{|c|c|c|}
\multicolumn{4}{|c|}{$[\text { Based on MFC }]^{1}$} \\
\hline Treatments & $\boldsymbol{\beta}$-actin & GLUT2 \\
\hline C & 1.00 & $1.00^{\mathrm{b}}$ \\
\hline W & 1.08 & $1.72^{\mathrm{a}}$ \\
\hline B & 1.07 & $1.80^{\mathrm{a}}$ \\
\hline SEM & 0.04 & 0.05 \\
\hline
\end{tabular}

${ }^{*}$ abc Means with different superscript letters within columns have significant difference $(\mathrm{P}<0.01) .{ }^{1} \mathrm{MFC}$ : Mean Fold Change. ${ }^{*}$ C:corn, W:wheat, B:barley. SEM: Standard Error of Mean.

\section{Discussion}

Results of the present study indicates that birds fed on wheat diet had lower feed intake and total weight gain resulted in higher feed conversion ratio (FCR) compared to other groups. Also birds fed on barley had increased feed intake compared to the wheat and corn diets with higher FCR. Nevertheless, birds fed on barley and wheat diets had lower body weight and higher FCR than their counterparts fed on corn diet (Table 2). Unfavorable effects of soluble NSP of wheat and barley well demonstrated through other reports [26, 30, 42]. Our results indicate that NSP of wheat (arabinoxylan polymers) have more deleterious impact on feed intake than $\beta$-glucans polymers of barley's NSP [19]. This means that cereal type of NSP has prominent effect on gut physicochemical properties which affected digesta viscosity and $\mathrm{pH}$, primarily due to passage rate and degree of bacterial activity throughout the gut $[7,26,42]$. In this study growth performance data were consistent with digesta physiochemical data $(\mathrm{pH}$ and viscosity in table 4), so that wheat and barley diets had lower $\mathrm{pH}$ and greater viscosity than corn diet. Generally, increased viscosity creates ideal environment for proliferation of pathogens such as anaerobic and Gram negative bacteria which they could reduce nutrients availability and produce detrimental by-products for host [6, 7]. These events lead to increased producing of short chain volatile fatty acids (SCVFAs) into lumen that finally resulted in decreased digesta $\mathrm{pH}[8,9,22]$. Our observations are in agreement with previous reports $[18,21,22,42]$.

According to results presented in table 5, reduced abdominal fat and liver percentage can resulted from increase of dietary fiber content of wheat and barley and effect of NSP on digesta physico-chemical properties which leads to quick changes in the intestinal passage rate and dynamic of digestion and absorption of nutrients due to increased viscosity of intestinal content [33]. Reduced abdominal fat deposition in the present study might be due to presence of viscose material in wheat and barley diets [26, 33]. Fibrous grains and their NSP content reduced bill acid secretion, binding nutrients via their web structures, impressed the hepatic-intestinal circulation, and strike the lipid emulsification through the gut which finally resulted in reduced lipid absorption and lipid uptake by the liver, so the lipogenesis rate of the liver is being reduced and conduced to down regulating of liver weight $[19,20,21]$. Therefore, it is concluded that the lower abdominal fat and liver percentage induced by wheat and barley diets are related to their dietary fiber and NSP content. Increased pancreas percentage and gut length are associated with increscent of dietary fiber inward the intestinal content. This situation leads to reduction of digesta passage rate due to increased bulk material which resulted in greater length and weight of gut in wheat and barley diets compared to corn diet $[17,19,24]$. Also again, high concentration of dietary fiber and NSP content 
of diets through the intestine could impair normal activity of pancreas due to lower permeability of digesta to internal digestive enzymes [21, 24, 25]. High viscose digesta impede action of digestive enzymes secreted from pancreas, so greater amount of enzymes needs to perform digestion and finally resulted in increased pancreas activity and weight of pancreas [21, 24, 41].

Results of table 6 demonstrate changes of serum immunoglobulin concentrations of chickens after feeding of different dietary sources of NSP at the age of 42 days. As mentioned later, serum IgG titer of birds fed on wheat diet was higher than corn or barley groups. This means that potential of wheat to agitation of immune system because of its NSPs (arabinoxylan polymers), and probably due to its anti-oxidative compounds (3), is more potent than barley or corn. Immunoglobulin $G$ (IgG) and immunoglobulin (IgM) are components of total serum immunoglobulin (humoral immunity) against foreign antigens [16]. Immunoglobulin $\mathrm{G}$ specialized for protect against antigens through the intercellular fluids. IgG is the most abundant type of antibody, is found in all body fluids and protects body against bacterial and viral infections. Immunoglobulin $M$ specialized for protect against antigens through the intracellular fluids. IgM is found mainly in the blood and lymph fluid, is the first antibody to be made by the body to fight a new infection [16,34]. Effect of different cereals on immune system depends on several factors such as genetic and variety of plant, growth condition and levels of nutrients as well as anti-nutrients in plant which well affected immune system and production of antibodies through the immune organelles such as bursa of fabricius and thymus [15]. The main factors affected on immune efficiency listed as nutrient levels of cereal grains, growth stimulating factors of immune system related to chemical composition of cereal grain (especially composition of omega3 and omega6 unsaturated fatty acids), anti-oxidant levels of cereal grains, especial active materials such as phenolic compounds, flavonoids, di and three terpenoids, carboxylic acid and some other similar compounds [2]. It is clear that, specific humoral immunity responses to nutrient deficiencies when chicken fed on different diets with different content of nutrients [4]. So we can conclude that chemical composition of wheat grain is completely different from corn and barley grains and this means that wheat and after that barley can alter physiological characteristics of chickens, in this case especially affected the immune competence and production of serum immunoglobulin.

Results of table 7 indicated that increase in expression of GLUT2 in the jejunum of chickens at age of 42 day fed wheat and barley diets may reflect disturbance effects of NSPs content of mentioned cereals on gut cell wall, villus structure and restoring the remodeled nutrient transporters which resulted in negative effects $(17,18,21)$. In the small intestine, the absorption of nutrients is mediated by transporter proteins expressed in the enterocyte. The nutrients passed through the epithelium of the small intestine and into the blood stream via special transporters [28]. Since the nutrient transporters have different gene expression patterns and actions, thus it can be concluded that it is necessary to understand the developmental patterns of intestinal absorptive capacity because of its key function in nutrient intake [27, 31, 32]. On the other hand, according to the literatures, content (including quantity and quality of food) and composition the nutrients (including type and abundance of nutrients) in the intestine is essential for development of intestinal absorptive cells. Inversely, existence of anti-nutrients in the gut causes disorder against intestinal development $[36,37,39,40]$.

Increasing the level and composition of carbohydrates consumed well over several days increases the density of glucose transmitters in the intestinal cell membranes and this increase along with an increase in mRNA levels of GLUT2 genes [10,11]. Plentitude of nutrient transmitters in the chicken intestine well affected by several factors such as genetic selection, the type and amount of feed intake, intestinal tissue growth and development, quality and quantity of dietary protein, as well as dietary fiber and NSPs level [5, 12-14, 28].

Food deprivation or presence of anti-nutrients such as NSPs especially water-soluble NSP compounds causing delay and disruption of intestinal tissue growth, increased synthesis and secretion of mucin and eventually changing the structure of the intestinal mucus layer $(36,37,38,39]$. The supply of nutrients and absorption of carbohydrates in the early growth period of 
the chickens has an important role in the normal development of intestinal tissue, mucus layer of the intestinal absorptive cells and other relevant events in the intestine [27, 28, 37, 40].

All of the incidents through the gut are set by regulating the gene expression of nutrient transmitters (glucose, amino acids and peptides) from lumen and through the mucus layer into enterocytes of lining surface at the absorptive area, which created in the intestine and are the main factors limiting further chicken growth $[10,11,13]$. In this experiment, wheat and barley diets were increased GLUT2 gene expression. Because high-fiber food with plentiful NSPs content led to increased digesta viscosity and resulted in reduced nutrients absorption rate in the intestinal absorptive cells which needs to high levels of nutrient transmitters such as GLUT2. It is obvious that, increase the level of nutrient transmitters per se needs to high level of mRNA for the gene of GLUT2 and increases the productive GLUT2 gene expression and GLUT2 synthesis rate [28, 31, $32,40]$.

\section{Conclusion}

According to the results of present study different sources of NSP due to increasing digesta viscosity have detrimental effects on growth and physiological response of broilers. In fact, different NSP components of wheat and barley compare to corn grain have adverse effects on gain and some organelle percentages but due to different antigenic agitation mode, serum immuglobulin concentrations of wheat and barley were higher than that of corn grain, which reflect the nature effect of different NSP sources. Besides, NSP polymers of wheat and barley compare to corn grain increase mRNA quantity and expression of GLUT2 gene, which means that plentitude of glucose transporter through intestinal cells in absorptive area responded to presence of NSP inside the gut environment truly.

\section{Acknowledgment}

Authors appreciate financial support of the Animal Research Institute, Karaj, Iran and technical support of the Shahrekord University, Shahrekord Iran.

\section{References}

[1] Association of Official Analytical Chemists (A.O.A.C). Official Methods of Analysis of the Association of Analytical Chemists International, 18th ed., 1st suppl. Gaithersburg, MD U.S.A, 2005.

[2] M. Akbari Gharaei et al., Effect of guar meal with and without $\beta$-mannanas enzyme on performance and immune response of broiler chicks, Inter. Res. J. Applied. Basic. Sci. 3 (2012) 2785-2793.

[3] B. Ahmadipour et al., Anti-oxidative, anti-hyperlipidemic, and growth-promoting effects of Kelossia odoratissima in meat-type chickens, Poult. Sci. J. 3(1) (2015) 37-46.

[4] K.H. Benny, J. Vanitha, Immunomodulatory and antimicrobial effects of some traditional Chinese medicinal herbs: A review, Curr. Med. Chem. 11 (2004) 1423-1430.

[5] H. Chen et al., Dietary protein level and stage of development effect expression of an intestine peptide transporter (cPepT1) in chickens, J. Nutr. 135 (2005) 193-198.

[6] M. Choct, G. Annison, The inhibition of nutrient digestion by wheat Pentosans, Br. J. Nutr. 67 (1992) 123-132.

[7] M. Choct, G. Annison, Aniti-Nutritive activity of wheat Arabinoxylans: Role of viscosity, J. Br. Poult. Sci. 33 (1992) 821-834.

[8] H. Hetland, M. Choct, B. Svihus, Role of insoluble non-starch polysaccharides in poultry nutrition. World's poul, Sci. J. 60 (2004) 415-422.

[9] D.M. Denbow, Gastrointestinal anatomy and physiology, in: Sturkie's avian physiology, $5^{\text {th }}$ ed. Academic Press, San Diego, 2000. 
[10] R.P. Ferraris, J. Diamond, Regulation of intestinal sugar transport, J. Physiol. Rev. 77 (1997) 257-302.

[11] R.P. Ferraris, Dietary and developmental regulation of intestinal sugar transport, J. Biochem. 360 (2001) 265-275.

[12] E.R. Gilbert et al., Developmental regulation of nutrient transporter and enzyme mRNA aboundance in the small intestine of broilers, Poult. Sci. 86 (2007) 1739-1753.

[13] E.R. Gilbert et al., Dietary protein quality and feed restriction influence abundance of nutrient transporter mRNA in the small intestine of broiler chicks, J. Nutr. 138 (2008) 262271.

[14] E.R. Gilbert et al., Dietary protein composition influences abundance of peptide and amino acid transporter messenger ribonucleic acid in the small intestine of 2 lines of broiler chicks, Poult. Sci. 89 (2010) 1663-1676.

[15] R. Jahanian, Immunological responses as affected by dietary protein and arginine concentrations in starting broiler chicks, Poult. Sci. 88 (2009) 1818-1824.

[16] C. Janeway, Immunobiology, $5^{\text {th }}$ ed., Garland Publishing, Garland Science Co. Academic Press, 2001.

[17] D. Jamroz et al., Digestibility and energy value of non-starch polysaccharides in young chickens, ducks and geese, fed diet containing high amount of barley, J. Comp. Biochem. Physiol. 131 (2002) 657-668.

[18] D. Jaroni et al., The effect of dietary wheat middling and enzyme supplementation. II: Apparent nutrient digestibility, digestive tract size, gut viscosity and gut morphology in two strains of leghorn hens, J. Poult. Sci. 78 (1999) 1664-1674.

[19] M. Kalantar et al., Thymus vulgaris L., Glycyrrhiza glabra or Combo® Enzyme in Corn vs. Barley-Based Broiler Diets, J. Coast. Life. Med. 2 (2014) 993-997.

[20] M. Kalantar, A. Yaghobfar, Animal model show physiological characteristics can alter by feeding of different cereal type and exogenous multi-enzyme, Int. J. Pharm. Phyto. Ethno. 2 (2016) 13-19.

[21] M. Kalantar, F. Khajali, A. Yaghobfar, Effect of cereal type and enzyme addition on performance, pancreatic enzyme activity, intestinal microflora and gut morphology of broilers, Poult. Sci. J. 4 (2016) 63-71.

[22] D.J. Langhout et al., Effect of dietary high-and low-methylated citrus pectin on the activity of the ileal micro flora and morphology of the small intestinal wall of broiler chicks, J. Br. Poult. Sci. 40 (1999) 340-347.

[23] K.J. Livak, T.D. Schmittgen, Analysis of relative gene expression data using real-time quantitative PCR and the $2^{-\Delta \Delta C t}$ method, Methods. 25(4) (2001) 402-408.

[24] W.F. Li et al., Effects of non-starch polysaccharides enzymes on pancreatic and small intestinal digestive enzyme activities in piglet fed diets containing high amounts of barley, World. J. Gastroenterol. 10 (2004) 856-859.

[25] P.H. Lin, B.I. Shih, J.C. Hsu, Effects of different source of dietary non-starch polysaccharides on the growth performance, development of digestive tract and activities of pancreatic enzymes in goslings, J. Br. Poult. Sci. 51 (2010) 270-277.

[26] S. Mirzaie et al., Effect of wheat inclusion and xylanase supplementation of the diet on productive performance, nutrient retention and endogenous intestinal enzyme activity of laying hens, J. Poult. Sci. 91 (2012) 413-425.

[27] E.T.Jr. Moran, Nutrition of the developing embryo and hatchling, Poult. Sci. 86 (2007) 1043-1049.

[28] C.R. Mott et al., Gene expression of transporters in the small intestine of chickens from lines divergently selected for high or low Junvenile body weight, Poult. Sci. 87 (2008) 22152224.

[29] National Research Council (N.R.C), Nutrient Requirements of Poultry. National Academy of Science. Washington, D. C, 1994. 
[30] O.A. Olukosi, A.J. Cowieson, O. Adeola, Age-related influence of a cocktail of xylanase, amylase, and protease or phytase individually or in combination in broilers, J. Poult. Sci. 86 (2007) 77-86.

[31] A. Smirnov, D. Sklan, Z. Uni, Mucin dynamics in the small intestine are altered by starvation, J. Nutr. 134 (2004)738-742.

[32] Smirnov et al., Mucin gene expression and mucin content in the chicken intestinal goblet cells are affected by in ovo feeding of carbohydrates, Poult. Sci. 85 (2006) 669-673.

[33] A.A. Saki et al., Various ratios of pectin to cellulose affect intestinal morphology, DNA quantitation, and performance of broiler chickens, J. Live. Sci. 139 (2011) 237-244.

[34] N. Sarker et al., Cell-mediated and humoral immunity and phagocytic ability in chicken's lines divergently selected for serum immunoglobulin M and G levels, Poult. Sci. 79 (2000) 1705-1709.

[35] SAS Institute. SAS procedure guide for personal computers, STAT User Guide, Statistics. Version 9.1. SAS Institute INC, Cary NC, 2004.

[36] H. Tanabe et al., Small intestine mucins are secreted in proportion to the setting volume in water if dietary indigestible components in rats, J. Nutr. 135 (2005) 2431-2437.

[37] Z. Uni, S. Ganot, D. Sklan, Posthatch development of mucosal function in the broiler small intestine, Poult. Sci. 77(1) (1998) 75-82.

[38] Z. Uni et al., Small intestine development in the young chick: Crypt formation and enterocyte proliferation and migration, Br. Poult. Sci. 41 (2000) 544-551.

[39] Z. Uni, A. Smirnov, D. Sklan, Pre- and posthatch development of goblet cells in the broiler small intestine: Effect of delayed access to feed, Poult. Sci. 82 (2003) 320-327.

[40] Z. Uni, P. Ferket, Methods for early nutrition and their potential. World's Poult, Sci. J. 60 (2004) 101-111.

[41] D.A. Williams, The pancreas, in: Strombeck's small animal gastroenterology, 3rd ed., Saunders, Philadelphia, 1996.

[42] Y.L. Yin, S.K. Baidoo, J.L.L. Boychuk, Effect of enzyme supplementation on the performance of broilers fed maize, wheat, barley or micronized dehulled barley diets, J. Anim. Feed. Sci. 9 (2000) 493-504. 